\title{
Respon Pertumbuhan dan Hasil Padi Sawah Organik Terhadap Residu Berbagai Macam Aplikasi Pupuk Hijau Glirisidia
}

\author{
Marti Winarni \\ Fakultas Pertanian, Universitas Merdeka Madiun, Jl. Serayu No.79, Madiun, 63133 \\ E-mail:martiwinarni@unmer-madiun.ac.id
}

\begin{abstract}
The object of the study was to obtain the residual the various of application of Glirisidia green manures on the growth and yield of organic rice lowland. The pot experiment was carried out in a randomized complete block design (RCBD) consisting of one factor and three replications. The factor was 10 residual the various of application of Glirisidia leaves that added the compost of cattle manures, namely: 100\% fresh Glirisidia leaves+0\% compost; 60\% fresh Glirisidia leaves $+40 \%$ compost; $40 \%$ fresh Glirisidia leaves+60\% compost; $100 \%$ wind-dried Glirisidia leaves+0\% compost; $60 \%$ of wind-dried Glirisidia leaves+40\% compost; $40 \%$ wind-dried Glirisidia leaves+60\% compost; $100 \%$ sun-dried Glirisidia leaves+0\% compost; $60 \%$ of the sun-dried Glirisidia leaves $+40 \%$ of compost; $40 \%$ of the sun-dried Glirisidia leaves+60\% compost; and $0 \%$ Glirisidia leaves $+100 \%$ compost. The results showed that the residual of Glirisidia leaves given in the form of fresh, wind-dried and sun-dried with a composition of $60 \%$ Glirisidia green manures $+40 \%$ compost, $40 \%$ composition of Glirisidia green manures $+60 \%$ compost and $100 \%$ compost without Glirisidia leaves supported growth, yield components and yield of organic lowland rice (an average of 140. $\mathrm{g} / \mathrm{hill}$ ) is higher than that of Glirisidia leaves $100 \%$ without added of cow manures (an average of $124.29 \mathrm{~g} / \mathrm{hill}$ ).
\end{abstract}

Keywords - : Glirisidia leaf; green manure; organic lowland rice; residue.

\section{PENDAHULUAN}

Penggunaan pupuk anorganik secara terus-menerus dan berlebihan setiap musim tanam menurunkan produktivitas tanah dalam jangka waktu tertentu (Ikemura \& Shukla, 2009; Hasanuzzaman et al., 2010; Sanati et al., 2011). Pertanian organik merupakan pertanian alternatif yang aman bagi lingkungan. Pertanian organik berkembang karena adanya ancaman kerusakan ekologis akibat pencemaran bahan anorganik (Jahroh, 2010). Pertanian organik bergantung pada kesehatan tanah dan daur hara melalui tanah menggunakan proses alami (Ram \& Sharma, 2011), mengandalkan sumber kebutuhan hara melalui pupuk organik dan masukan-masukan alami lainnya. Pupuk organik yang digunakan dalam pengelolaan tanah pertanian secara garis besar dibagi menjadi tiga kelompok utama, yaitu: pupuk kandang, kompos dan pupuk hijau. Pada umumnya, petani menggunakan pupuk kandang sapi sebagai sumber nutrisi, terutama nitrogen $(\mathrm{N})$, namun keberadaan pupuk kandang sapi sangat terbatas.

Pupuk hijau legum tahunan merupakan salah satu pupuk organik yang berpotensi sebagai sumber bahan organik tanah dan unsur hara tanaman padi sawah N. Salah satu jenis pupuk hijau legum tahunan dari jenis Glirisidia memiliki kadar N tinggi dan dekomposisnya cukup cepat. Kandungan kadar N daun Glirisidia segar adalah N 4,14\%, daun Glirisidia kering angin 3,13\%, daun Glirisidia kering matahari 3,34\% dan kompos pupuk kandang sapi memiliki kadar N 1,49\% (Winarni, 2016; Winarni, 2018). Nitrogen adalah suatu unsur nutrisi merupakan komponen asam amino, protein, asam nukleat, klorofil, enzim, hormon dan beberapa metabolit esensial lain (Wijaya, 2010; Lakitan, 2012; Sugito, 2012). Tanaman padi menyerap ion-ion NH4 ${ }^{+}$atau NO3 $^{-}$dan mengasimilasikannya menjadi molekul organik, seperti asam amino, amida, amina, protein serta asam nukleat. Pupuk hijau pada umumnya diaplikasikan dalam bentuk segar, namun terdapat masalah pengumpulannya yang memerlukan waktu yang cukup lama. Pupuk hijau dalam bentuk telah tersimpan untuk beberapa hari atau dalam bentuk kering menjadi alternatif aplikasinya karena bahan pupuk hijau dapat dipersiapkan lebih awal sebelum penanaman tanaman padi.

Penelitian yang telah dilakukan oleh Winarni et al. (2016) menunjukkan bahwa daun Glirisidia dengan dosis $20 \mathrm{t} / \mathrm{ha}$ meningkatkan karakter fisiologis, pertumbuhan tanaman dan hasil panen gabah. Hasil penelitian Winarni (2018) menunjukkan bahwa tidak ada perbedaan pengaruh aplikasi daun Glirisidia dalam bentuk segar, kering angin dan Glirisidia kering matahari. Aplikasi daun Glirisidia dalam bentuk segar 100\% + kompos 0\%, daun Glirisidia kering angin 100\% + kompos 0\% dan daun Glirisidia kering matahari $100 \%$ + kompos $0 \%$ mampu memberikan pertumbuhan tanaman dan hasil panen gabah yang tinggi.

Hasil penelitian Tomar et al. (2013) bahwa selama tahun pertama dan kedua, komponen hasil dan hasil padi lebih tinggi dalam plot NPK dibandingkan dengan pupuk hijau daun. Pada tahun ketiga, pupuk daun hijau (kecuali Alnus) mencapai produksi bahan kering dan hasil lebih tinggi dibandingkan perlakuan NPK dosis rekomendasi, namun respons lebih baik pada perlakuan Erythrina. Setelah panen akhir, N-tersedia tanah meningkat 14-20\% pada plot yang diberi perlakuan Alnus dan Erythrina dibandingkan dengan kontrol. 
Website : http://agritek.unmermadiun.ac.id/index.php/agritek

Penelitian yang dilakukan Alagappan \& Venkitaswamy (2015) mempelajari aspek berbagai sumber pupuk organik dibandingkan dengan praktek pengelolaan hara terpadu (integrated nutrient management, INM) RDF + Dhaincha (Sesbania cannabina) dan pupuk dosis rekomendasi (recommended dose of fertilizer, RDF) terhadap pertumbuhan dan hasil padi. Hasil penelitian menunjukkan bahwa perlakuan pupuk organik 100\% RDN melalui pupuk hijau Dhaincha mencapai nilai SPAD dan hasil gabah padi tertinggi.

Penelitian yang dilakukan Manjappa (2014) menunjukkan bahwa hasil panen gabah dan jerami nyata dipengaruhi oleh aplikasi berbagai taraf Eupatorium selama kedua tahun dan rerata hasil. Hasil gabah padi dengan aplikasi Eupatorium pada perlakuan $10 \mathrm{t} / \mathrm{ha}$ dan $20 \mathrm{t} / \mathrm{ha}$ ditemukan setara satu sama lain. Hasil jerami maksimum diperoleh dengan Eupatorium 20 t/ha, namun setara dengan Eupatorium pada taraf 10 t/ha.

Hasil penelitian Neelima (2008) menunjukkan bahwa bobot kering maksimal tanaman padi ditemukan dengan pembenaman total tanaman $\left(1306 \mathrm{~g} / \mathrm{m}^{2}\right)$ dan tajuk $\left(1264 \mathrm{~g} / \mathrm{m}^{2}\right)$ Sunnhemp dan aplikasi $180 \mathrm{~kg} / \mathrm{ha} \mathrm{N}\left(1233 \mathrm{~g} / \mathrm{m}^{2}\right)$. Hasil gabah padi nyata lebih tinggi dengan pembenaman total Sunnhemp atau tajuk Sunnhemp. Keseimbangan $\mathrm{N}$ tanah dengan pembenaman tanaman total atau tajuk Sunnhemp dan $180 \mathrm{~kg} / \mathrm{ha} \mathrm{N}$.

Residu aplikasi pupuk hijau dalam berbagai macam bentuk secara terpadu bersamaan dengan kompos pupuk kandang dalam komposisi yang tepat belum banyak dilaporkan. Oleh karena itu perlu dilakukan penelitian tentang residu berbagai bentuk aplikasi pupuk hijau yang dicampur dengan kompos pupuk kandang sapi dengan komposisi yang tepat untuk medapatkan hasil panen gabah yang maksimal.Tujuan penelitian ini adalah untuk mengkaji pengaruh residu berbagai macam bentuk aplikasi pupuk hijau Glirisidia yang dicampur dengan kompos pupuk kandang sapi dalam berbagai koposisi terhadap pertumbuhan dan padi sawah organik.

\section{BAHAN DAN METODE}

Penelitian menggunakan Rancangan Acak Kelompok Lengkap (RAK) faktor tunggal dan tiga ulangan. Faktor perlakuan tersebut adalah residu aplikasi daun Glirisidia sebanyak 10 macam, yaitu: Daun Glirisidia Segar 100\%; daun Glirisidia Segar $60 \%$ + kompos 40\%, daun Glirisidia Segar 40\%+ kompos 60\%); daun Glirisidia kering angin 100\% + kompos 0\%; daun Glirisidia kering angin 60\% + kompos 40\%; daun Glirisidia kering angin 40\% + kompos 60\%; daun Glirisidia kering matahari $100 \%+$ kompos $0 \%$; daun Glirisidia kering matahari $60 \%+$ kompos $40 \%$ ); daun Glirisidia kering matahari $40 \%+$ kompos $60 \%$ ); dan daun Glirisidia 0\% + kompos 100\%).

Persiapan Tanah dilakukan dengan cara dikering-anginkan, ditumbuk dan disaring dengan ayakan dengan diameter 2 mm. Tanah sebanyak $40 \mathrm{~kg}$ dimasukkan ke dalam ember plastik dengan ukuran lebar $60 \mathrm{~cm}$ dan tinggi $40 \mathrm{~cm}$, kemudian digenangi. Pupuk hijau daun Glirisidia dengan $25 \mathrm{t} / \mathrm{ha}(500 \mathrm{~g} / \mathrm{pot})$ dibenamkan dalam tanah yang telah dimasukkan dalam pot dengan kedalaman $10 \mathrm{~cm}$ sesuai perlakuan. Tanah selanjutnya digenangi air dengan ketinggian $5 \mathrm{~cm}$ sampai 2 minggu sebelum panen. Sedangkan kompos pupuk kandang dengan $25 \mathrm{t} /$ ha $(500 \mathrm{~g} / \mathrm{pot})$ dibenamkan dalam tanah bersamaan dengan waktu tanam sesuai perlakuan.

Setelah pupuk hijau diaplikasikan ke dalam pot dan digenangi selama 2 minggu, bibit padi varietas Ciherang yang telah berumur 3 minggu setelah sebar dipindahtanamkan sebanyak 3 bibit per lubang dan empat rumpun setiap ember. Penjarangan dilakukan setelah tanaman berumur 2 mst dengan menyisakan 2 (dua) tanaman setiap pot.

Pengumpulan data pertumbuhan tanaman diambil secara distruktif dengan 2 rumpun sampel pada fase pertumbuhan vegetatif cepat (5 minggu setelah tanam, mst), fase pertumbuhan tanaman maksimal (10 mst) dan pada saat panen (15 mst). Data komponen hasil dan hasil panen padi diamati pada saat panen. Pengamatan meliputi variabel-variabel tinggi tanaman (cm), luas daun per rumpun $\left(\mathrm{cm}^{2}\right)$, jumlah anakan maksimal per rumpun, dan bobot kering tanaman per rumpun (g). Komponen hasil dan hasil panen diamati pada saat panen terhadap variabel-variabel jumlah malai/rumpun, jumlah gabah per malai, bobot 1000 butir gabah, hasil Panen Gabah/Rumpun (g).

Data hasil pengamatan yang diperoleh dianalisis dengan menggunakan Analisis Ragam (Analisis of Variance) pada taraf nyata 5 persen. Perbedaan antar perlakuan dianalisis dengan Uji Berjarak Duncan (Duncan Multiple Range Test $=$ DMRT) pada taraf nyata 5\%. Data diolah dengan menggunakan program SAS versi 9.1.3.

\section{III.HASIL DAN PEMBAHASAN}

\section{A. Pertumbuhan Tanaman Padi}

Residu aplikasi berbagai macam pupuk hijau daun Glirisidia berpengaruh terhadap pertumbuhan tanaman padi, yang ditunjukkan pada variabel tinggi tanaman, jumlah anakan/rumpun, dan bobot kering tanaman. Residu pupuk hijau daun Glirisidia dengan berbagai macam aplikasi yang dicampur dengan kompos pupuk kandang memberikan pengaruh yang berbeda terhadap tinggi tanaman padi. Rerata tinggi tanaman pada perlakuan residu berbagai macam aplikasi pupuk hijau glirisidia disajikan pada Tabel 1 .

Tabel 1 menunjukkan bahwa residu pupuk hijau yang diberikan dalam bentuk segar, kering angin dan kering matahari dengan komposisi $40 \%$ pupuk hijau Glirisidia $+60 \%$ kompos pupuk kandang menghasilkan rerata tinggi tanaman tertinggi dan berbeda nyata dibandingkan dengan komposisi $60 \%$ pupuk hijau Glirisidia $+40 \%$ kompos pupuk kandang dalam bentuk dan $100 \%$ 
Website : http://agritek.unmermadiun.ac.id/index.php/agritek

pupuk hijau Glirisidia $+0 \%$ pupuk kandang. Rerata tinggi tanaman serta terendah diperoleh pada perlakuan residu aplikasi $100 \%$ pupuk hijau Glirisidia $+0 \%$ pupuk kandang dalam bentuk segar, kering angin dan kering matahari. Perlakuan residu pupuk hijau daun Glirisidia dengan berbagai macam aplikasi yang ditambah dengan kompos pupuk kandang sapi memberikan pengaruh yang berbeda terhadap jumlah anakan/ rumpun padi. Residu pupuk hijau yang diberikan dalam bentuk segar, kering angin dan kering matahari dengan komposisi $40 \%$ pupuk hijau Glirisidia $+60 \%$ kompos pupuk kandang komposisi $60 \%$ pupuk hijau Glirisidia $+40 \%$ kompos pupuk kandang menghasilkan rerata jumlah anakan/ rumpun yang tidak berbeda nyata, nyata lebih tinggi dibandingkan dengan 100\% pupuk hijau Glirisidia + 0\% pupuk kandang (Tabel 1)

Bobot kering tanaman dipengaruhi oleh perlakuan residu pupuk hijau daun Glirisidia dengan berbagai macam aplikasi yang dicampur dengan kompos pupuk kandang. Residu pupuk hijau yang diberikan dalam bentuk segar, kering angin dan kering matahari dengan komposisi $40 \%$ pupuk hijau Glirisidia $+60 \%$ kompos pupuk kandang komposisi $60 \%$ pupuk hijau Glirisidia + $40 \%$ kompos pupuk kandang menghasilkan rerata bobot kering tanaman/ rumpun yang tidak berbeda nyata, tetapi nyata lebih tinggi dibandingkan dengan perlakuan residu 100\% pupuk hijau Glirisidia + 0\% pupuk kandang (Tabel 1).

Tabel 1. Rerata Tinggi Tanaman, Jumlah Anakan dan Bobot Kering Tanaman pada Perlakuan Residu Berbagai Macam Aplikasi Pupuk Hijau Glirisidia

\begin{tabular}{|c|c|c|c|}
\hline Macam Residu Aplikasi Daun Glirisidia & $\begin{array}{c}\text { Tinggi Tanaman } \\
(\mathbf{c m})\end{array}$ & $\begin{array}{c}\text { Jumlah Anakan/ } \\
\text { Rumpun }\end{array}$ & $\begin{array}{c}\text { Bobot Kering } \\
\text { Tanaman/ Rumpun }\end{array}$ \\
\hline Glirisidia Segar $100 \%+$ Kompos $0 \%$ & $71.67 \mathrm{c}$ & $12.33 \mathrm{~b}$ & $22.33 \mathrm{~b}$ \\
\hline Glirisidia Segar $60 \%+$ Kompos $40 \%$ & $76.67 \mathrm{~b}$ & $14.00 \mathrm{a}$ & $23.00 \mathrm{a}$ \\
\hline Glirisidia Segar $40 \%+$ Kompos $60 \%$ & $80.33 \mathrm{a}$ & $13.33 \mathrm{a}$ & $26.33 \mathrm{a}$ \\
\hline Glirisidia kering angin $100 \%+$ Kompos $0 \%$ & $72.67 \mathrm{c}$ & $12.00 \mathrm{~b}$ & $23.00 \mathrm{~b}$ \\
\hline Glirisidia kering angin $60 \%+$ Kompos $40 \%$ & $76.33 \mathrm{~b}$ & $13.33 \mathrm{a}$ & $26.33 \mathrm{a}$ \\
\hline Glirisidia kering angin $40 \%+$ Kompos $60 \%$ & $81.67 \mathrm{a}$ & $13.67 \mathrm{a}$ & $26.67 \mathrm{a}$ \\
\hline Glirisidia kering matahari $100 \%+$ Kompos $0 \%$ & $72.33 \mathrm{c}$ & $12.33 \mathrm{~b}$ & $23.00 \mathrm{~b}$ \\
\hline Glirisidia kering matahari $60 \%+$ Kompos $40 \%$ & $76.33 \mathrm{~b}$ & $12.33 \mathrm{~b}$ & $26.33 \mathrm{a}$ \\
\hline Glirisidia kering matahari $40 \%+$ Kompos $60 \%$ & $80.67 \mathrm{a}$ & $13.67 \mathrm{a}$ & $26.67 \mathrm{a}$ \\
\hline Glirisidia $0 \%+$ Kompos $100 \%$ & $81.67 \mathrm{a}$ & $14.33 \mathrm{a}$ & $27.33 \mathrm{a}$ \\
\hline Rerata & 77.033 & 13.23 & 25.43 \\
\hline KK $(\%)$ & 2.51 & 3.93 & 5.18 \\
\hline
\end{tabular}

Keterangan: Angka-angka yang didampingi huruf sama pada kolom yang sama tidak beda nyata pada uji Duncan 5\%

\section{B. Komponen Hasil dan Hasil Panen}

Residu aplikasi pupuk hijau daun Glirisidia yang dicampur dengan kompos pupuk kandang sapi dalam berbagai macam bentuk aplikasi berpengaruh terhadap komponen hasil panen padi, yang ditunjukkan pada variabel jumlah malai/rumpun, panjang malai, jumlah biji/rumpun dan hasil panen gabah/ rumpun. Rerata jumlah malai/rumpun, panjang malai, jumlah biji/rumpun dan hasil panen gabah/ rumpun pada perlakuan residu berbagai macam aplikasi pupuk hijau daun Glirisidia disajikan pada Tabel 2 .

Tabel 2. Rerata Jumlah Malai/ Rumpun, Panjang Malai, Jumlah Biji/Malai dan Padi pada Perlakuan Residu Berbagai Macam Aplikasi Pupuk Hijau Glirisidia

\begin{tabular}{lcccc}
\hline \multicolumn{1}{c}{ Macam Aplikasi Daun Glirisidia } & $\begin{array}{c}\text { Jumlah Malai/ } \\
\text { Rumpun }\end{array}$ & $\begin{array}{c}\text { Panjang Malai } \\
\left(\mathbf{c m}^{2}\right)\end{array}$ & $\begin{array}{c}\text { Jumlah } \\
\text { Biji/Malai }\end{array}$ & $\begin{array}{c}\text { Hasil Gabah/ } \\
\text { Rumpun (g) }\end{array}$ \\
\hline Glirisidia Segar 100\% + Kompos 0\% & $10.33 \mathrm{~b}$ & $22.50 \mathrm{~b}$ & $100.33 \mathrm{~b}$ & $123.27 \mathrm{~b}$ \\
Glirisidia Segar 60\% + Kompos 40\% & $12.00 \mathrm{a}$ & $24.60 \mathrm{a}$ & $104.67 \mathrm{~b}$ & $138.07 \mathrm{a}$ \\
Glirisidia Segar 40\% + Kompos 60\% & $12.67 \mathrm{a}$ & $25.63 \mathrm{a}$ & $127.00 \mathrm{a}$ & $142.27 \mathrm{a}$ \\
Glirisidia kering angin 100\% + Kompos 0\% & $10.67 \mathrm{~b}$ & $22.60 \mathrm{~b}$ & $104.00 \mathrm{~b}$ & $123.07 \mathrm{~b}$ \\
Glirisidia kering angin 60\% + Kompos 40\% & $12.00 \mathrm{a}$ & $24.53 \mathrm{a}$ & $108.67 \mathrm{~b}$ & $139.07 \mathrm{a}$ \\
Glirisidia kering angin 40\% + Kompos 60\% & $12.67 \mathrm{a}$ & $25.00 \mathrm{a}$ & $127.67 \mathrm{a}$ & $137.53 \mathrm{a}$ \\
Glirisidia kering matahari 100\% + Kompos 0\% & $10.67 \mathrm{~b}$ & $22.43 \mathrm{~b}$ & $108.33 \mathrm{~b}$ & $126.53 \mathrm{~b}$ \\
Glirisidia kering matahari 60\% + Kompos 40\% & $13.00 \mathrm{a}$ & $24.60 \mathrm{a}$ & $112.67 \mathrm{~b}$ & $141.33 \mathrm{a}$ \\
Glirisidia kering matahari 40\% + Kompos 60\% & $12.00 \mathrm{a}$ & $25.17 \mathrm{a}$ & $127.67 \mathrm{a}$ & $141.00 \mathrm{a}$ \\
Glirisidia 0\% + Kompos 100\% & $12.67 \mathrm{a}$ & $25.43 \mathrm{a}$ & $131.67 \mathrm{a}$ & $142.13 \mathrm{a}$ \\
\hline Rerata & 11.87 & 24.25 & 115.40 & 7.03 \\
CV (\%) & 4.84 & 4.38 & 135.43 \\
\hline
\end{tabular}

Keterangan: Angka-angka yang didampingi huruf sama pada kolom yang sama tidak beda nyata pada uji Duncan 5\%

Tabel 2 menunjukkan bahwa rerata jumlah malai/rumpun tidak berbeda nyata akibat perlakuan residu pupuk hijau yang diberikan dalam bentuk segar, kering angin dan kering matahari dengan komposisi $40 \%$ pupuk hijau Glirisidia $+60 \%$ kompos 
Website : http://agritek.unmermadiun.ac.id/index.php/agritek

pupuk kandang komposisi $60 \%$ pupuk hijau Glirisidia $+40 \%$ kompos pupuk kandang, namun nyata lebih tinggi dibandingkan dengan residu aplikasi $100 \%$ pupuk hijau Glirisidia $+0 \%$ pupuk kandang.

Penggunaan residu pupuk hijau Glirisidia dengan berbagai macam bentuk aplikasi berpengaruh terhadap panjang malai. Rerata panjang malai tidak berbeda nyata akibat perlakuan residu pupuk hijau yang diberikan dalam bentuk segar, kering angin dan kering matahari dengan komposisi $40 \%$ pupuk hijau Glirisidia $+60 \%$ kompos pupuk kandang komposisi $60 \%$ pupuk hijau Glirisidia $+40 \%$ kompos pupuk kandang, namun nyata lebih tinggi dibandingkan dengan residu aplikasi 100\% pupuk hijau Glirisidia $+0 \%$ pupuk kandang (Tabel 2).

Residu aplikasi pupuk hijau daun Glirisidia dengan berbagai macam aplikasi mampu mempengaruhi jumlah biji/malai padi yang dihasilkan. Rerata jumlah biji/ malai tidak berberda nyata akibat perlakuan residu pupuk hijau yang diberikan dalam bentuk segar, kering angin dan kering matahari dengan komposisi $40 \%$ pupuk hijau Glirisidia $+60 \%$ kompos pupuk kandang sapi, komposisi $60 \%$ pupuk hijau Glirisidia $+40 \%$ kompos pupuk kandang sapi, namun nyata lebih tinggi dibandingkan dengan residu aplikasi $100 \%$ pupuk hijau Glirisidia + 0\% kompos pupuk kandang sapi (Tabel 2)

Rerata hasil panen gabah/ rumpun tidak berberda nyata akibat perlakuan residu pupuk hijau yang diberikan dalam bentuk segar, kering angin dan kering matahari dengan komposisi $40 \%$ pupuk hijau Glirisidia $+60 \%$ kompos pupuk kandang komposisi $60 \%$ pupuk hijau Glirisidia $+40 \%$ kompos pupuk kandang, namun nyata lebih tinggi dibandingkan dengan residu aplikasi 100\% pupuk hijau Glirisidia + 0\% pupuk kandang (Tabel 2).

\section{Pembahasan}

Residu pupuk hijau daun Glirisidia yang diaplikasikan dengan berbagai bentuk yang dicampur dengan kompos pupuk kandang dalam berbagai komposisi mempengaruhi pertumbuhan tanaman padi. Hal ini ditunjukkan pada variabel tinggi tanaman, jumlah anakan/ rumpun, dan bobot kering tanaman. Residu pupuk hijau yang diberikan dalam bentuk segar, kering angin dan kering matahari dengan komposisi $40 \%$ pupuk hijau Glirisidia $+60 \%$ kompos pupuk kandang menghasilkan rerata tinggi tanaman tertinggi dan berbeda nyata dibandingkan dengan komposisi $60 \%$ pupuk hijau Glirisidia $+40 \%$ kompos pupuk kandang dalam bentuk dan $100 \%$ pupuk hijau Glirisidia $+0 \%$ pupuk kandang. Rerata tinggi tanaman serta terendah diperoleh pada perlakuan residu aplikasi 100\% pupuk hijau Glirisidia $+0 \%$ pupuk kandang dalam bentuk segar, kering angin dan kering matahari (Tabel 1).

Residu pupuk hijau yang diberikan dalam bentuk segar, kering angin dan kering matahari dengan komposisi $40 \%$ pupuk hijau Glirisidia $+60 \%$ kompos pupuk kandang komposisi 60\% pupuk hijau Glirisidia $+40 \%$ kompos pupuk kandang menghasilkan rerata jumlah anakan/rumpun dan bobot kering tanaman yang tidak berbeda nyata, tetapi nyata lebih tinggi dibandingkan dengan residu 100\% pupuk hijau Glirisidia + 0\% pupuk kandang sapi (Tabel 1). Perbedaan pengaruh residu aplikasi pupuk hijau Glirisidia dengan berbagai bentuk yang dicampur dengan kompos pupuk kandang sapi dalam berbagai komposisi. Hal ini disebabkan karena kompos pupuk kandang sapi telah mengalami proses dekomposisi selama proses pengomposan, sehingga sisa bahan organik yang berupa kompos merupakan bahan organik yang sulit lapuk (recalcitrant) yang tersimpan dalam tanah dan bersifat imobilisasi sehingga unsur hara tidak tersedia bagi tanaman.

Makin tinggi prosentase kompos pupuk kandang sapi yang dicampurkan dengan pupuk hijau Glirisidia, makin banyak residu bahan organik yang bersifat imobilisasi di dalam tanah, sehingga pengaruhnya lebih baik terhadap pertumbuhan tanaman padi pada musim tanam ke dua. Residu bahan organik yang bersifat imobilisasi di dalam tanah, sehingga pengaruhnya lebih baik terhadap pertumbuhan tanaman padi pada musim tanam ke dua. Residu pupuk organik akan terdekomposisi dan melepaskan unsur hara, termasuk $\mathrm{N}$. Kondisi ketersediaan $\mathrm{N}$ dalam tanah menentukan jumlah $\mathrm{N}$, yang dapat diserap oleh tanaman (Purwanto et al., 2014). Nitrogen adalah komponen dari asam amino, protein, asam nukleat, klorofil dan banyak metabolik penting lainnya untuk kelangsungan hidup tanaman. Tanaman yang diberikan pasokan $\mathrm{N}$ cukup akan membentuk daun yang lebih luas dan kandungan klorofil yang lebih tinggi, sehingga tanaman mampu menghasilkan jumlah asimilasi untuk yang cukup menopang pertumbuhan vegetatif (Wijaya, 2008).

Sebaliknya, makin tinggi prosentase pupuk hijau Glirisidia dalam komposisi aplikasi (100\% pupuk hijau Glirisidia tanpa kompos pupuk kandang), makin cepat makin cepat mengalami proses dekomposisi dan mineralisasi bahan organik, sehingga lebih sedikit bahan organik yang imobilisasi. Hal ini menyebabkan ketersediaan unsur hara bagi pertumbuhan tanaman padi pada masa tanam kedua lebih sedikit, sehingga menyebabkan rendahnya pertumbuhan tanaman.

Residu pupuk hijau daun Glirisidia yang diaplikasikan dengan berbagai bentuk yang dicampur dengan kompos pupuk kandang sapi dalam berbagai komposisi memberikan pengaruh yang berbeda terhadap komponen hasil dan hasil panen padi yang ditunjukkan oleh variabel jumlah malai/rumpun, panjang malai, jumlah biji/malai dan bobot gabah/rumpun (Tabel 2).

Residu pupuk hijau yang diberikan dalam bentuk segar, kering angin dan kering matahari dengan komposisi $60 \%$ pupuk hijau Glirisidia + 40\% kompos pupuk kandang menghasilkan rerata jumlah malai, panjang malai dan hasil gabah/ rumpun tidak berbeda nyata dengan komposisi $40 \%$ pupuk hijau Glirisidia + 60\% kompos pupuk kandang sapi serta 100\% kompos kandang sapi, namun nyata lebih tinggi dibandingkan dengan residu komposisi $100 \%$ pupuk hijau Glirisidia $+0 \%$ pupuk kandang sapi.

Residu pupuk hijau yang diberikan dalam bentuk segar, kering angin dan kering matahari dengan komposisi $60 \%$ pupuk hijau Glirisidia $+40 \%$ kompos pupuk kandang menghasilkan rerata hasil gabah/ rumpun tidak berbeda nyata dengan komposisi 40\% pupuk hijau Glirisidia + 60\% kompos pupuk kandang sapi serta 100\% kompos kandang sapi sebanyak $137.53-142.27 \mathrm{~g} /$ 
Website : http://agritek.unmermadiun.ac.id/index.php/agritek

rumpun (rerata $140.2 \mathrm{~g}$ / rumpun) gabah kering giling (GKG). Sedangkan residu komposisi 100\% pupuk hijau Glirisidia $+0 \%$ pupuk kandang sapi memberikan hasil panen 123.07 - 126.53g (rerata 124,29 g/ rumpun) GKG.

Kandungan hara dalam residu kompos pupuk kandang sapi cukup tinggi dan diserap oleh tanaman padi sebagai sumber hara setelah mengalami proses dekomposisi. Residu pupuk organik mampu meningkatkan pertumbuhan tanaman padi, sehingga menyebabkan peningkatan komponen hasil. Peningkatan jumlah malai per rumpun, panjang malai, dan bobot 1000 biji menyebabkan peningkatan hasil gabah kering giling/rumpun.

\section{IV.KESIMPULAN DAN SARAN}

\section{A. Kesimpulan}

Residu aplikasi berbagai macam pupuk hijau daun Glirisidia yang dicampur dengan kompos pupuk kandang sapi dengan berbagai komposisi memberikan pengaruh yang berbeda terhadap pertumbuhan, komponen hasil dan hasil panen padi sawah organik. Residu pupuk hijau yang diaplikasikan dalam bentuk segar, kering angin dan kering matahari dengan komposisi $60 \%$ pupuk hijau Glirisidia yang dicampur dengan 40\% kompos pupuk kandang sapi dan komposisi 40\% pupuk hijau Glirisidia yang dicampur dengan $60 \%$ kompos pupuk kandang sapi mampu mendukung pertumbuhan tanaman, komponen hasil dan hasil panen padi sawah organik lebih baik dibandingkan dengan daun Glirisidia 100\% tanpa campuran pupuk kandang sapi. Residu pupuk hijau yang diaplikasikan dalam bentuk segar, kering angin dan kering matahari dengan komposisi $60 \%$ pupuk hijau Glirisidia yang dicampur dengan $40 \%$ kompos pupuk kandang sapi dan komposisi $40 \%$ pupuk hijau Glirisidia yang dicampur dengan $60 \%$ kompos pupuk kandang sapi memberikan hasil panen padi sawah organik (137.53 - 142.27 g/ ha GKG) lebih baik dibandingkan dengan daun Glirisidia 100\% tanpa campuran pupuk kandang sapi (123.07 - $126.53 \mathrm{~g} / \mathrm{ha}$ GKG).

\section{B. Saran}

Daun Glirisidia dapat digunakan sebagai pupuk hijau yang diaplikasikan dalam bentuk segar, kering angin atau kering matahari. Jika ketersediaan daun Glirisidia melimpah, maka budidaya padi organik dapat dilakukan dengan aplikasi daun Glirisidia 100\% (25 t/ha atau $500 \mathrm{~g} / \mathrm{pot}$ ) baik dalam bentuk segar, kering angin atau kering matahari. Perlu pengembangan penelitian lebih lanjut tentang budidaya padi sawah organik dengan aplikasi daun Glirisidia yang dikombinasikan pupuk hayati.

\section{UCAPAN TERIMAKASIH}

Ucapan terimakasih disampaikan kepada Rektor Universitas Merdeka Madiun yang telah memberikan bantuan dana penelitian sehingga penelitian ini dapat terlaksana.

\section{VI.DAFTAR PUSTAKA}

Alagappan, S. and Venkitaswamy, R. 2015. Development of spad values for rice variety Co (R) 48 while using various sources of organic manures in comparison with Rdf and Inm at different growth stages of rice for attaining optimum yield. Australian Journal of Basic and Applied Sciences 9(35): 122-125.

Hasanuzzaman, M., K.U. Ahamed, N.M. Rahmatullah, N. Akhter, K. Nahar \& M.L. Rahman. 2010. Plant Growth Characters and Productivity of Wetland Rice (Oryza sativa L, ) as Affected by Application of Different Manures. Emir. Food Agricultural Journal. Vol. 22 (1) : 46-58.

Ikemura, Y. \& K.M. Shukla. 2009. Soil Quality in Organic and Conventional Farms of New Mexico. USA. Journal of Organic Systems. Vol. 4 (1).

Jahroh, S. 2010. Organic Farming Development in Indonesia: Lessons Learned from Organic Farming in West Java and North Sumatra. ISDA. Montpellier. June 28-30

Lakitan, B. 2012. Dasar-dasar Fisiologi Tumbuhan. PT. Raja Grafindo Persada. Jakarta. 205 p.

Manjappa, K. 2014. Utilization of Eupatorium (Chromoleana odorata), an obnoxious weed as green leaf manure in enhancing rice productivity. IOSR Journal of Agriculture and Veterinary Science 7 (10): 46-48.

Neelima, T.L. \& V.B.B. Murthy. 2008. Growth and Yield Attributes Rice as Influenced by N fertilizer and Differential Incorporation of Sunnhemp Green Manure. Journal of Rice Research. 2 (1) : 45-50.

Tomar, J.M.S., Das, A. and Arunachalam A. 2013. Crop response and soil fertility as influenced by green leaves of indigenous agroforestry tree species in a lowland rice system in northeast India. Agroforestry Systems 87 (1):193-201

Sugito, Y. 2012. Ekologi Tanaman: Pengaruh Faktor Lingkungan terhadap Pertumbuhan Tanaman dan Beberapa Aspeknya. Universitas Brawijaya Press. Malang. 119 p.

Wijaya, K.A. 2008. Nutrisi Tanaman: Sebagai Penentu Kualitas Hasil dan Resistensi Alami Tanaman. Prestasi Pustaka. Jakarta. 121 p.

Winarni, M., Yudono, P., Indradewa, D., Sunarminto, B.H. 2016. Application of Perennial Legume Green Manures to Improve Growth and Yield of Organic Lowland Rice. Journal Degraded and Mining Land Management. 4 (1) : 671-674

Winarni, M. 2018. Peningkatan pertumbuhan dan hasil padi sawah organik dengan berbagai macam aplikasi pupuk hijau Glirisidia. 16 (4) : $76-81$. 